\title{
Assessing the Dynamic Economic Impact of Tourism in a Developing Region in South Africa
}

\author{
De Bruyn, C., Meyer, N., Meyer, D. F \\ North-West University, South Africa \\ chanedb@hotmail.co.za, Natanya.meyer@nwu.ac.za, Daniel.meyer@nwu.ac.za
}

\begin{abstract}
According to the National Development Plan (NDP), the three main developmental problems South Africa is facing include: high levels of unemployment, poverty and inequality. Tourism, as an economic sector, has been cited as a possible solution to create much-needed employment and income which could lead to reduced poverty and improved inequality. Tourism could be used in developing regions as a driver of economic growth. The objective of this study is to determine the dynamic impact of the tourism sector on economic growth in a developing region in South Africa, namely the Vaal-Triangle region. The research methodology followed a quantitative design, using a pooled panel approach including the two municipal areas of Metsimaholo and Emfuleni which comprises the Vaal region. Annual data from 2001 to 2017 were used to analyse the impact of growth in tourism on economic growth. Economic growth was set as the dependent variable and tourism measurements such as tourism spending and trips as the independent variables. Results from the analysis confirm the original hypothesis that tourism growth has a significant impact on economic growth. The sector therefore, has the potential to create employment opportunities and alleviate poverty in a developing region if promoted and supported to its full potential.
\end{abstract}

Keywords: Economic development, economic impact, South Africa, tourism, Vaal-Triangle region.

\section{Introduction}

While some countries are succeeding in decreasing unemployment and poverty, there is still more than 65 percent of the world's population living on less than $\$ 2$ per day, per person (Todaro \& Smith, 2015). This includes South Africa where high unemployment and poverty levels are obstacles in reaching sustainable economic growth. The poor often find themselves restricted with limited choices and not able to get out of the poverty trap due to a lack of skills, knowledge and opportunities (Ashley, De Brine \& Wilde, 2007). With this being said, tourism development is regarded as one approach that has the potential to aid marginalised communities and people in overcoming this stagnation (Butler \& Rogerson, 2016). The tourism sector is one of the world's largest industries and one of the fastest growing economic sectors (Seghir, Mostéfa, Abbes \& Zakarya, 2015). Tourism has become one of the major players in international commerce and at the same time it acts as one of the main sources of income for many developing countries, such as South Africa (UNWTO, 2016). According to Meyer and Meyer (2015) tourism, as an alternative to traditional economic sectors such as manufacturing and construction and it can act as a tool to alleviate poverty and promote economic development especially in developing countries.

Harrill (2004) defines tourism as all forms of travel, which unlike other industries, infuses communities through its influence on the community environment, employment, land use and social structures. Samini, Sadeghi and Sadeghi (2011) state that tourism acts as a driving engine for economic growth and economic activity. Furthermore, tourism creates employment opportunities, therefore increasing income and government tax revenues, increases an area's export, which in turn increase gross domestic product (GDP) and therefore economic growth (Samani et al., 2011; Zuo \& Huang, 2017). As a result, this growth leads to an increase in the economic diversification of a region and creates a competitive edge for regions (Meyer \& Meyer, 2015). Diversification of local economies is important especially for local regions that are only depended on one or two economic sectors as these regions are highly vulnerable to economic shocks and business cycle fluctuations (Pedrana, 2013). In such cases, the diversification of a local economy minimises the vulnerability of that particular area to economic disturbances.

Despite this, tourism is frequently overlooked as one of the most important economic sectors (Richardson, 2010). Many governments do not perceive tourism as an important and significant sector to contribute towards economic growth and development, which often results in a lack of empirical research to advise policymakers (Croes \& Vanegas, 2008). As Phiri (2016) points out, there is limited academic research on the industry's precise impact on economic growth and development in countries, especially in developing nations 
such as South Africa. Even less research is available on how tourism influences economic growth on a regional and local level. In the South African scenario, it is important to gain a deeper understanding of the impact of tourism on the economic growth of communities. This necessitates the need to analyse and measure how many, if any, marginalised communities are in actual fact benefited by the development of tourism and how inclusive tourism growth really is (Hanekom, 2015). Hence, the focus of this study is the Vaal region in South Africa, which consists of the local municipal areas of Metsimaholo and Emfuleni and for the rest of the study, the region is referred to as the Vaal region. The aforementioned prompted this study in an effort to contribute to the lack of literature surrounding tourism and its dynamic impact on local economies.

\section{Literature Review}

Poverty has its worst exposure in developing countries, where these countries form part of the frailest segment of the international community (Croes \& Vanegas, 2008). In order to combat unemployment, inequality and poverty, rapid inclusive growth should be sought after (Giampiccoli \& Saayman, 2016). As Giampiccoli and Saayman (2016) surmise, inclusive growth can be explained as a phenomenon where the benefits of economic growth are shared equitably in order to increase opportunities, capabilities and incomes of households in the country. Tourism utilised as a key socio-economic driver, has the ability to promote investment in local firms, create work opportunities, increase export revenues and aid in infrastructure development, thus ultimately contributing to the economic growth of a region (Pedrana, 2013). Economic growth can be seen as an increase in a country or region's aggregate production (GDP) or the measurable output per capita (the average GDP per person) (Fourie \& Burger, 2011; Van den Berg, 2012). Over the past few decades and on an international level, the tourism industry has been progressively expanding, increasing the sector's share in the economies of both developing and developed countries (Seghir et al., 2015). Tourism can be defined as the movement of people from one place to another, for more than one night due to various reasons, such as medical, cultural, recreational and business engagements (Pedrana, 2013).

As Butler and Rogerson (2016) assert, tourism has the potential to empower young people and women as well as marginalised populations. Tourism allows for job opportunities for all people regardless of their level of education, age, gender and race. This is because the industry plays a particularly important role in areas that struggle with low levels of per capita GDP, high unemployment rates and competition from cheap imports, since it also allows for skills development and employment opportunities (Samini et al., 2011). Emphasise should be placed on the importance tourism has as a multiplier effect, due to the direct and indirect economic benefits that it creates to a local community (Meyer \& Meyer, 2015). The multiplier effect can be explained as an initial capital investment, leading to various direct and indirect economic opportunities. Despite this, local governments often fail to prioritise tourism and realise its potential contributions to Local Economic Development (LED) (Croes \& Vanegas, 2008). LED is a pro-active process in which local people from all sectors of the community work together to stimulate local commercial activity, which results in a sustainable, growing local economy (Trousdale, 2005). As a result of the aforementioned, policy decisions are usually aimed at achieving unrealistic goals that are not within the community's skills framework. Hence, the community should be incorporated into the development processes to ensure that the benefits arising from tourism development are spread equally throughout the local economy.

In addition, it often happens that stakeholders from developed countries dictate those from developing nations in the best ways of improving tourism development (McLachlan \& Binns, 2014). This usually results in high levels of leakages within the tourism industry, high levels of foreign ownership, high inequality, loss of resources, cultural loss as well as spatial unevenness (McLachlan \& Binns, 2014). High levels of leakages refer to when the benefits resulting from the tourism industry are not spread through to the local economy, rather to an external and sometimes international beneficiary. With this being said, tourism needs to be recognised as important because it will give people without high skills levels and knowledge a chance to earn a salary, improve their skill set and their overall standard of living, which ultimately could contribute to economic growth and development (Lanza \& Pigliaru, 2000). When analysing the Sub-Saharan African region, South Africa has the most developed tourism market (JLL, 2012). This is due to the country having vast regions of natural beauty, coastlines, safari parks, developed cities and relatively well-developed infrastructure, and a fairly stable economy, which offers a strong proposition to tourists (BMI, 2016). The recent political 
instability may in future have a negative impact on tourism and needs to be managed. Furthermore, the country is seen as Africa's economic powerhouse which attracts people (BMI, 2016).

Figure 1: Tourism's Direct Contribution in Percentage to the Economy (GDP) of South Africa for the Past 10 Years

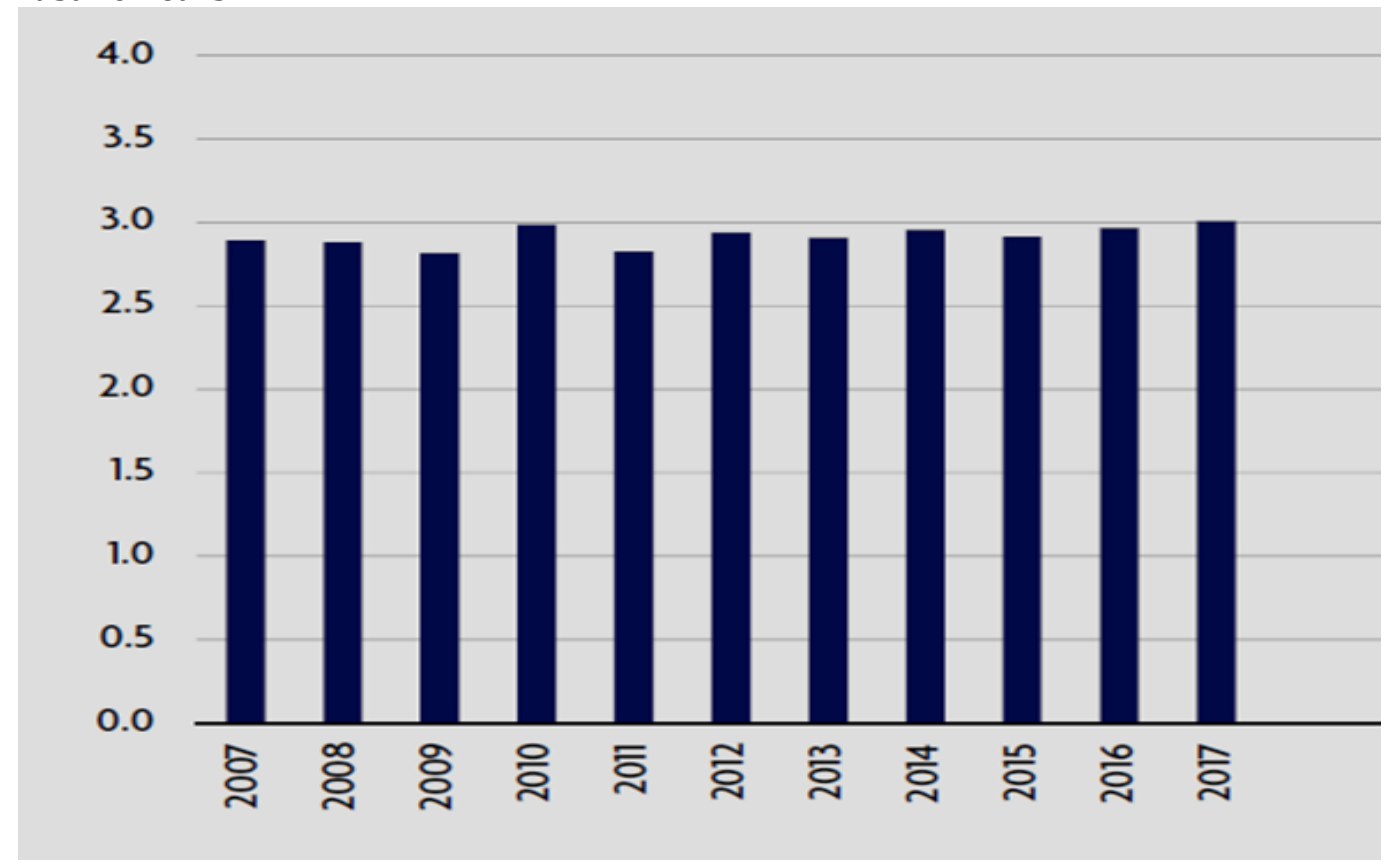

Source: WTTC (2017a)

In 2016 the sector directly contributed 3 percent to South Africa's GDP and it is expected to increase with 2.7 percent in 2017. In addition, the total contribution of the travel and tourism industry (which includes the direct and indirect effects of tourism) to GDP in South Africa was 9.3 percent in 2016 (WTTC, 2017a). The direct contribution of tourism to the country's economy (GDP) includes the growth from industries in the tourism sector such as travel agents, hotels, restaurants, travel agencies and other leisure agencies that are directly supported by tourists (WTTC, 2017a). As can be seen from Figure 1, the industry saw a peak during 2010, which may be as a result of the Soccer World Cup. This emphasises the importance of hosting large international gatherings such as sports and cultural events. In contrast to 2010, the industry had a lower growth rate in 2015 when compared to 2014. According to the new regulations those wishing to travel to South Africa had to apply for their visas, in person, at a South African embassy where all of their biometric information had to be recorded (SAinfo, 2015). Furthermore, all children under the age of 18, who are travelling in or out of South Africa had to have an unabridged birth certificate at entry ports that had to include the full details of both their parents as well as in the case of travelling with only one parent they must be accompanied by a consent letter from the parent not travelling with them (SAinfo, 2015). The aforementioned resulted in a significant decrease in inbound arrivals. The growth rate of inbound arrivals in 2015 was a mere 1, 8 percent when compared to a growth rate of almost 6 percent in 2014 (BMI, 2016).

The South African government realised the damage brought on by the new visa regulations and have since relaxed visa requirements and the period of 2016 has seen an increase in visitor numbers. With this being said, the tourism industry in general and in particular South Africa is still not without its challenges. If the correct policies and effective management strategies are not in place it may lead to the deterioration of the environment, pollution and a loss of biodiversity (Creaco \& Querini, 2003). Another area of concern is the possibility that with the arrival of new cultures and their ways, the social and cultural context of the community may be affected and certain unique cultural features may be lost (Pedrana, 2013). According to George (2015) tourism in South Africa is seen as one of the key drivers of LED, however, the sector still remains under-acknowledged for its potential contribution to economic growth and development on a national and regional scale (Butler \& Rogerson, 2016). Regarding the study area, the Vaal region has a total 
population of over 900000 people according to the 2017 statistics, which constitutes over 6 percent of the Gauteng province's total population (Global Insight, 2017). Figure 2 illustrates the tourism industry's contribution to the economy of the Vaal-Triangle (GDP) over the past decade. Although its contribution has declined since 2006, it has been increasing since 2015, to an average of 2.2 percent.

Figure 2: The Tourism Sector's Regional Economic Contribution (\%)

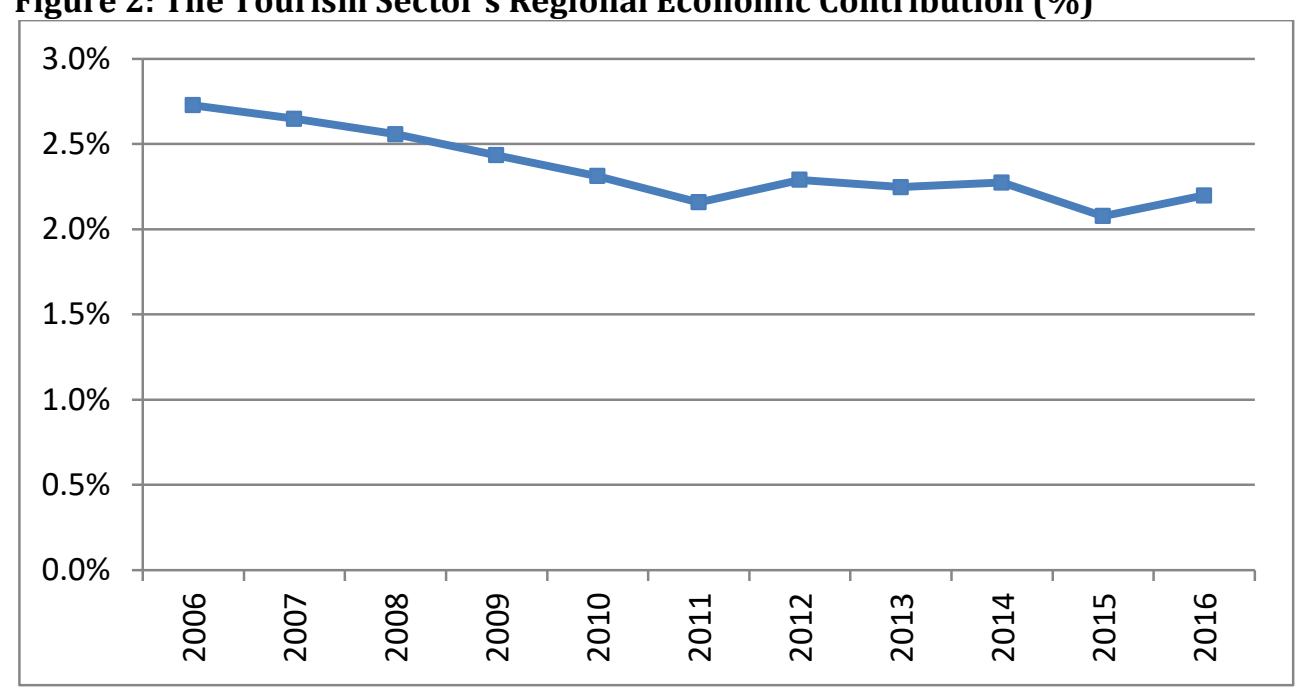

Source: Global Insight (2017)

Within the Emfuleni municipal area, the contribution was the largest at 2.6 percent in 2016 . This may be as a result of tight visa regulations implemented during that period. Tourism spending in the region has also seen an increase, as is illustrated in Figure 3. Total tourism spending in the Vaal-Triangle has increased substantially in 2016, as is evident from Figure 3. This rise has a significant positive effect on the regions GDP. Another positive is the increase in total tourism trips to the area, which amounted to over 400000 trips in 2016 (Insight, 2017). Of this, the largest group of trips were for holiday/recreational reasons. These figures indicate that tourism in the Vaal-Triangle has the potential to develop and could indeed act as a new way of routing the local economy.

Figure 3: Total Tourism Spending (R1000)

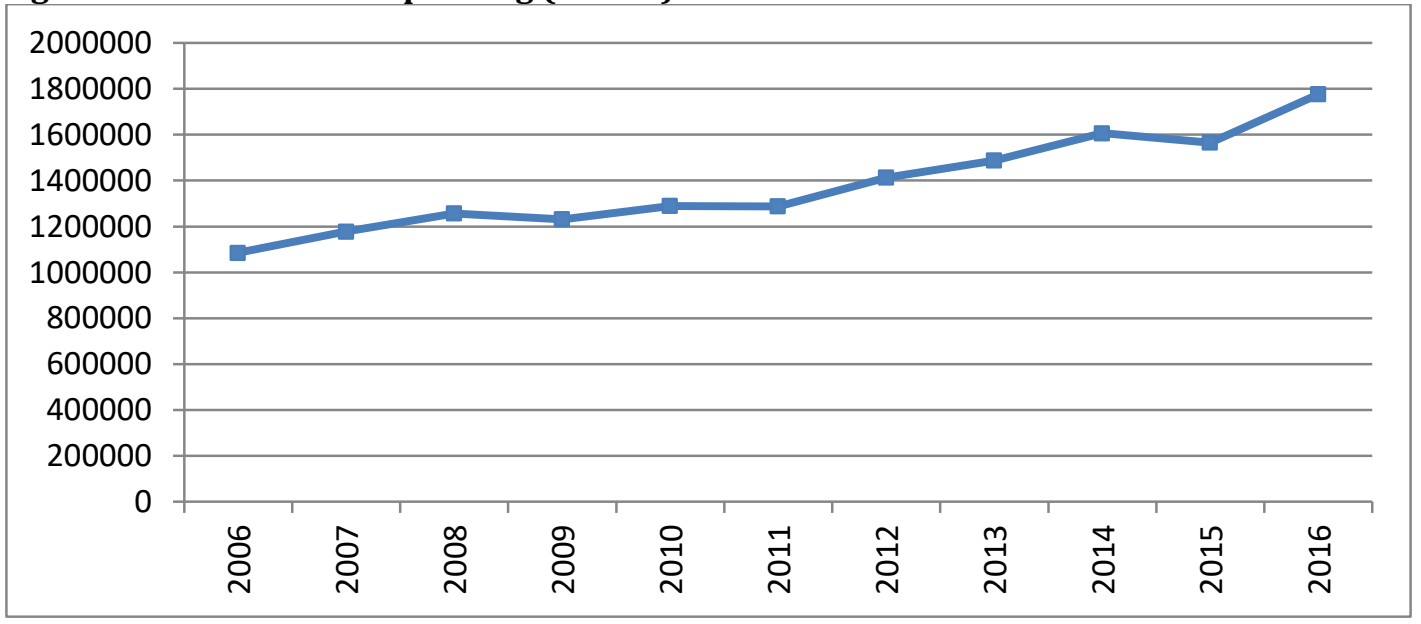

Source: Global Insight (2017)

It should be noted however, that when incorrectly managed, the tourism industry may bring with it a number of negative influences. These negative impacts, however, can be minimised and avoided if the correct policies and management practices are in place, where the community is involved and there is a strong co-operation 
between the private and public sector. This will ensure that the tourism industry plays a central role in protecting and advancing the social and cultural integrity of a community, while promoting the benefits of tourism and at the same time addressing and minimising the potential negative effects (WTTC, 2017b).

\section{Methodology}

The focus area, as mentioned earlier, is the Vaal-Triangle region situated in South Africa. This area was chosen due to the following reasons. Firstly, it is situated on the periphery of the Johannesburg economic region, secondly, it is rich in cultural and historical places and events. Thirdly, the area is situated next to a major water body namely the Vaal River contributing to its touristic potential and lastly the area shows potential for tourism development, especially when looking at its characteristics. The Vaal-Triangle region consists of the Emfuleni Local Municipal area (Gauteng Province) and the Metsimaholo Local Municipal area (Free State Province). It is located approximately $120 \mathrm{~km}$ from Pretoria and $80 \mathrm{~km}$ from Johannesburg (Local Government Handbook, 2016) and both municipalities are situated on the banks of the Vaal River. Consequently, the region has several opportunities for economic and tourism development. The Vaal-Triangle region has well-developed entertainment venues, sports facilities, shopping centres, hotels, guesthouses and restaurants (Meyer, 2015). The area enjoys an admirable climate and it has an abundance of fauna and flora. The Vaal-Triangle has the relatively good infrastructure and can benefit from being so closely located to Johannesburg, the economic hub of Africa (Meyer, 2015). Based on the aforementioned information, the main objective of this research study is to assess the dynamic economic impact of tourism in the Vaal-Triangle region of South Africa, with the use of a time series approach.

In an effort to analyse the impact of growth in tourism on that of economic growth, the research design consisted of a quantitative method with the use of secondary data from Global Insight. Annual data from 2001 to 2017 were used and analysed by using a pooled panel approach pooling the two municipal areas of Metsimaholo and Emfuleni which forms the Vaal-Triangle region. The variables used in the analysis consisted of economic growth (GDP), tourism spending, total tourism trips and the hospitality sector (restaurants and hotels). The data was analysed with the use of E-views software. Data from the Vaal-Triangle region were used in a panel data set, where a multiple regression was utilised. Multiple regression is a regression where multiple variables (influences) affect the dependent variable, thus instead of having only one independent variable, there are now several (Gujarati \& Porter, 2010). The variables were set as follow:

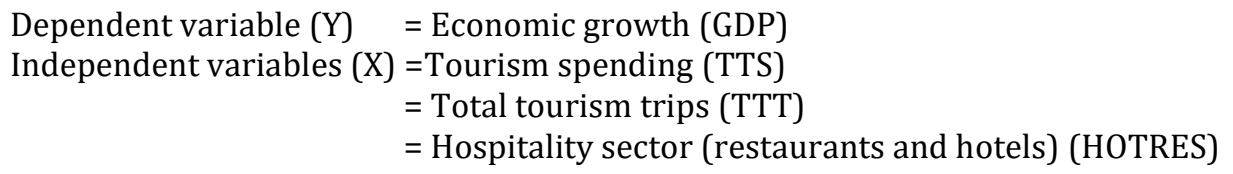

Pedroni (2004) formulated the following equation for panel data, which was utilised for this study:

$Y_{i t}=a_{i}+\delta_{i} t+\beta_{i} X_{i t}+e_{i t}$

Where:

$Y_{i t}=$ Dependent variable

$a_{i}=$ Intercept term

$\delta_{i}=$ Parameter that together with $a_{i}$ allows the individual linear trends and individual effects to be observed respectively (Seghir et al., 2015).

$\beta=\mathrm{k} \times 1$ vector of parameters that were estimated based on the explanatory variables.

$X_{i t}=1 \times \mathrm{k}$ vector of observations of the explanatory variables, $\mathrm{t}=1, \mathrm{~T} ; \mathrm{i}=1$.

In an effort to reduce the scale of the data all of the variables in the regression were converted into logarithms.

\section{Results and Discussion}

The following section explains the results obtained from the quantitative analysis. Table 1 illustrates the results obtained from the unit root testing. The tests used for the purpose of this study included theLevin, Lin 
and Chu (LLC), Im, Pesaran and Shin (IPS), Augmented Dickey-Fuller (ADF) and Phillips-Perron (PP) unit root tests. The purpose of unit root tests is to, overtime; bring the series variance, mean and auto-covariance to a steady state (Habanabakize, 2016). In addition, the unit root test should be the first step taken before conducting the co-integration estimations, as the use of non-stationary variables may produce spurious results (Ogbokor, 2015). In addition, other supporting results have been found by Antonakakis, Dragouni and Filis (2015) in the case of Italy and the Netherlands. As such, this evidence suggests that there is indeed causality running from tourism development to economic growth in the Vaal-Triangle region. This result however, contradicts those of Eugenio-Martin, Morales and Scarpa (2004) who found no causality between tourism and economic growth as well as Balcilar, van Eyden and Inglesi-Lotz (2014), who found no causality between tourism and economic growth in the case of South Africa.

Table 1: Panel Unit Root Tests

\begin{tabular}{llll}
\hline Variables & Tests & P-Value & Level \\
\hline \multirow{4}{*}{ GDP } & LLC & $0.0005^{* *}$ & $\mathrm{I}(1)$ \\
& IPS & $0.0494^{* *}$ & $\mathrm{I}(1)$ \\
& ADF & $0.0465^{* *}$ & $\mathrm{I}(1)$ \\
TTT & PP & $0.0001^{* *}$ & $\mathrm{I}(1)$ \\
& LLC & $0.0014^{* *}$ & $\mathrm{I}(1)$ \\
& IPS & $0.0065^{* *}$ & $\mathrm{I}(1)$ \\
TTS & ADF & $0.0094^{* *}$ & $\mathrm{I}(1)$ \\
& PP & $0.0025^{* *}$ & $\mathrm{I}(1)$ \\
& LLC & 0.9003 & $\mathrm{I}(1)$ \\
\multirow{3}{*}{ HOTRES } & IPS & $0.0308^{* *}$ & $\mathrm{I}(1)$ \\
& ADF & $0.0310^{* *}$ & $\mathrm{I}(1)$ \\
& PP & $0.0001^{* *}$ & $\mathrm{I}(1)$ \\
& LLC & $0.0034^{* *}$ & $\mathrm{I}(1)$ \\
\hline
\end{tabular}

** indicates variables are statistically significant at 5\%

As can be seen in Table 1, all of the variables are stationary after $1^{\text {st }}$ differenced or I(1) level and significant at a 5 percent level. The next question to be addressed is to determine the direct nexus between tourism and economic growth. For this reason, the Johansen Fisher panel co-integration test is utilised as this test is most suitable when all variables are of order I(1). The results are presented in Table 2.

Table 2: The Johansen Fisher panel co-integration test

\begin{tabular}{|c|c|c|c|c|}
\hline $\begin{array}{l}\text { Hypothesized } \\
\text { No. of CE(s) }\end{array}$ & $\begin{array}{l}\text { Fisher Stat. } \\
\text { (from trace test) }\end{array}$ & Probability & $\begin{array}{l}\text { Fisher Stat. } \\
\text { (from Max-Eigen } \\
\text { test) }\end{array}$ & Probability \\
\hline None & 81.41 & $0.0002 *$ & 38.84 & 0.0003* \\
\hline At most 1 & 51.03 & $0.0005^{*}$ & 31.93 & 0.0006* \\
\hline At most 2 & 23.21 & $0.0001 *$ & 23.21 & $0.0001 *$ \\
\hline At most 3 & 5.150 & 0.2722 & 5.150 & 0.2722 \\
\hline
\end{tabular}

* indicates variables are statistically significant at $1 \%$

In order to establish that there is indeed a long-run relationship between the variables that earlier tests suggested, the Johansen Fisher co-integration test is used. Seghir et al. (2015) define co-integration as the methodical co-movement between variables in the long-run. From analysing the results in Table 2 the tests indicate that the Trace and Max-Eigen test provides evidence of a co-integrating relationship between the variables, at a 1 percent significance level. Therefore, it could be concluded that the results obtained from the Johansen Fisher co-integration test provide confirmation that there is a long-run equilibrium relationship between tourism and economic growth. The subsequent step is to determine the exact impact of tourism on economic growth in the Vaal-Triangle region. In order to determine the impact of tourism on economic 
growth and development, the Fully Modified Ordinary Least Squares (FMOLS) and the Dynamic Ordinary Least Squares (DOLS) models were applied. Table 3 presents the FMOLS and DOLS results for the determination of tourism's impact on economic growth. Here economic growth (LOG_GDP) is the dependent variable, with tourism spending (LOG_TTS), tourism trips (LOG_TTT) and the hospitality sector (LOG_HOTRES) representing the independent variables.

Table 3: FMOLS and DOLS Results

\begin{tabular}{llllll}
\hline Method & Variables & Coefficient & Std. Error & t-statistic & Prob. \\
\hline \multirow{3}{*}{ FMOLS } & TTT & 0.160555 & 0.157648 & 1.018439 & 0.3182 \\
& TTS & 0.103343 & 0.116723 & 0.885370 & 0.3844 \\
& HOTRES & 0.553375 & 0.218097 & 2.537293 & $0.0178^{*}$ \\
\multirow{2}{*}{ DOLS } & TTT & 1.367717 & 0.399954 & 3.419684 & $0.0419^{*}$ \\
& TTS & 1.048875 & 0.572741 & 3.577312 & $0.0374^{*}$ \\
& HOTRES & 1.623288 & 0.941880 & 2.785162 & $0.0487^{*}$ \\
\hline
\end{tabular}

*significant at $5 \%$

Dependent variable: GDP

Independent variable: LOG_TTS, LOG_TTT and LOG_HOTRES

The FMOLS and especially the DOLS results indicate that there is indeed a positive, long-run relationship between tourism and economic growth. The FMOLS result suggests that a 1 percent increase in the hospitality sector will most likely lead to a 0.55 percent increase in economic growth. The DOLS result suggest that a 1 percent increase in tourism trips, tourism spending and the hospitality sector will most likely lead to a 1,37 percent, 1,05 percent and 1,62 percent increase, respectively, in economic growth. This provides evidence that tourism can improve the economic growth of a region. In addition, Po and Huang (2008) also found in an analysis of 57 countries that a 1 percent increase in tourism development could lead to an increase of 0.115 percent in economic growth. Seeing that previous tests have confirmed the existence and positive impact of tourism on economic growth, it is still necessary to determine causality between variables. Hence, the following step involves the use of the Granger Causality test. The aim of the Granger causality test is to establish whether it is the dependent variable driving the independent variable or the independent variable driving the dependent variable (Rivera, 2017). Table 4 reports on the results from the Granger causality tests.

\section{Table 4: Granger Causality Tests}

\begin{tabular}{lc}
\hline Null Hypothesis & Probability \\
\hline LOG_HOTRES does not Granger Cause LOG_GDP & $0.0250^{*}$ \\
LOG_GDP does not Granger Cause LOG_HOTRES & 0.4765 \\
LOG_TTT does not Granger Cause LOG_GDP & 0.5978 \\
LOG_GDP does not Granger Cause LOG_TTT & $0.0475^{*}$ \\
LOG_TTS does not Granger Cause LOG_GDP & $0.0386^{*}$ \\
LOG_GDP does not Granger Cause LOG_TTS & 0.1242 \\
\hline
\end{tabular}

Notes: ${ }^{*}$ rejection of the null hypothesis at $5 \%$ significance level

** rejection of the null hypothesis at a $10 \%$ significance level

It is evident from the results in Table 4 that causality proceeds from tourism to economic growth in the shortrun. This phenomenon is supported by similar studies such as that of Balaguer and Cantavella-Jorda (2002), Dubarry (2004), Holzner (2011) and Narayan, Sharma and Bannigidadmath (2013). They found a causality running from tourism development to economic growth in their respective studies of Spain and Mauritius. In addition, similar results were found in a 134 country analysis and Pacific Island countries. Furthermore, there is causality from GDP to the total number of tourism trips, which suggest that as economic growth increases and the local government is able to invest more in the local infrastructure, tourism in the area is likely to increase as a result. Adding to the various aforementioned statistical procedures, diagnostic statistics were also used. When referring to econometric analyses it is necessary to determine whether or not the residuals were distributed normally. In order to achieve this, the histogram of the residuals device was used. With regard to autocorrelation, both tests had AC values above 0.5, which suggested that there was no 
autocorrelation between the variables. The results further suggested that there were no conditional heteroscedasticity and serial correlation. Both the histogram of residuals and the Jarque-Bera statistic show that the data was normally distributed and the results gained are valid.

\section{Conclusion and Recommendations}

The main aim of this study was to assess the dynamic economic impact of tourism in the Vaal-Triangle region of South Africa. Research on the impact of tourism on economies has been relatively new when compared to other fields and the impact the industry has on economic growth in local regions has received restricted attention. The findings that arose from the study suggest that tourism does indeed have a positive impact on economic growth in the Vaal-Triangle region. This study provided significant results, as it adds in reducing the uncertainty surrounding tourism and its impact on local economies. It was found that the tourism industry could contribute between 1,37 to 2,62 percent to economic growth. This indicates that tourism does have the potential in decreasing unemployment and furthermore contribute to alleviating poverty and improve the standards of living for people in local regions. Local government support is essential together with establishing close net relations between the community and the private and public sectors. Establishing a governing institution could aid in developing new projects, sharing of new solutions and information, promoting sustainability and lead to improved coordination among industry leaders. Corporate social responsibility together with sustainability could form part of the newly formed legislation, whereby especially tourism operators should be required to adhere to certain predetermines for operating within the region. Furthermore, with synergy between the public and private sectors, the natural environment and its resources would be able to more effectively protected, as well as improve the region's marketing, branding and image building.

It is worth mentioning that no study is without its limitations. Firstly, the findings of this study are based on the results of testing two municipal areas and results may differ across other local regions. These aforementioned shortcomings do however pave the way for possible areas for future research as instead of only focussing on the Vaal-Triangle region, future research could include more local regions across South Africa.In conclusion, studies such as this could aid in indicating that the tourism industry does not only have the potential to promote economic growth, but create representations and meaningful attributes for a region. Especially for a developing nation such as South Africa with its rich biodiversity, historical and cultural assets, tourism could be the key factor to enrich the lives of many South Africans, irrespective of race, gender, culture, religion and age.

\section{References}

Antonakakis, N., Dragouni, M. \& Filis, G. (2015). How strong is the linkage between tourism and economic growth in Europe? Economic Modelling, 44, 142-155.

Ashley, C., De Brine, P. \& Wilde, H. (2007). The role of the tourism sector in expanding economic opportunity. Corporate Social Responsibility Initiative Report. Cambridge, MA: Harvard University.

Balaguer, J. \& Cantavella-Jorda, M. (2002). Tourism as a long-run economic growth factor: The Spanish case. Applied Economics, 34(7), 877-884.

Balcilar, M., van Eyden, R. \& Inglesi-Lotz, R. (2014). Time-varying linkages between tourism receipts and economic growth in South Africa. Applied Economics, 46(36), 4381-4398.

BMI (Business Monitor International). (2016). South Africa Tourism Report Q3 2016. London: BMI.

Butler, G. \& Rogerson, C. M. (2016). Inclusive local tourism development in South Africa: Evidence from Dullstroom. Local Economy, 31(1-2), 264-281.

Creaco, S. \& Querini, G. (2003). The role of tourism in sustainable economic development. European Regional Science Association, 1(1), 1-13.

Croes, R. \& Vanegas, M. (2008). Co-integration and causality between tourism and poverty reduction. Journal of Travel Research, 47(1), 94-103.

Dubarry, R. (2004). Tourism and economic growth: The case of Mauritius. Tourism Economics, 10(4), 389401.

Eugenio-Martin, J. L., Morales, N. M. \& Scarpa, R. (2004). Tourism and economic growth in Latin American countries: A panel data approach. FEEM Working paper, 26. 
Fourie, F. C. N. \& Burger, P. (2011). How to think and reason in Macroeconomics. $3^{\text {rd }}$ ed. Claremont: Juta \& Co Ltd.

George, X. (2015). Promoting integrated tourism at local government and its implications. Paper presented at Local Government Tourism Conference, Kempton Park, 30-31.

Giampiccoli, A. \& Saayman, M. (2016). Community-based tourism: From a local to a global push. Acta Commercii, 16(1), 1-10.

Global Insight. (2017). Data analysis. https://g-insight.org/what/\#data-analysis Date of access: 25 May 2017.

Gujarati, D. N. \& Porter, D. C. (2010). Essentials of econometrics. $4^{\text {th }}$ ed. New York: McGraw-Hill Education.

Habanabakize, T. (2016). A cross-sector analysis of the interaction between aggregate expenditure and job creation in South Africa. Vanderbijlpark: NWU. (Thesis - M. Com).

Hanekom, D. (2015). Local government tourism conference, Kempton Park, 30-31 March.

Harrill, R. (2004). Residents' attitudes toward tourism development: A literature review with implications for tourism planning. Journal of Planning Literature, 18(3), 251-266.

Holzner, M. (2011). Tourism and economic development: The beach disease? Tourism Management, 32(4), 922-933.

JLL (Jones Lang LaSalle). (2012). Sub-Saharan Africa: A region with opportunities amid transparency challenges. London: JLL.

Lanza, A. \& Pigliaru, F. (2000). Why are tourism countries small and fast growing? (In Fossati, A. \& Panella, G., eds. Tourism and sustainable economic development. Dordrecht: Kluwer, 57-69).

Local Government Handbook. (2016). Sedibeng district municipality. http://localgovernment.co.za /districts/view/14/Sedibeng-District-Municipality Date of access: 29 May, 2017.

McLachlan, S. \& Binns, T. (2014). Tourism, development and corporate social responsibility in Livingstone, Zambia. Local Economy, 29(1-2), 98-112.

Meyer, D. F. \& Meyer, N. (2015). The role and impact of tourism on local economic development: A comparative study. African Journal for Physical, Health Education, Recreation and Dance, 21(1-1), 197-214.

Meyer, D. F. (2015). Tourism the solution to the accelerated development of the Vaal Triangle region. http://www.news.nwu.ac.za/tourism-solution-accelerated-development-vaal-triangle-region-drdanie-meyer. Date of access: 4 April, 2017.

Narayan, P. K., Sharma, S. S. \& Bannigidadmath, D. (2013). Does tourism predict macroeconomic performance in Pacific Island countries? Economic Modelling, 33, 780-786.

Ogbokor, C. A. (2015). Foreign trade and economic growth in Namibia: A time series analysis. Vanderbijlpark, NWU. (Thesis - PhD).

Pedrana, M. (2013). Local economic development policies and tourism: An approach to sustainability and culture. Regional Science Inquiry Journal, 5(1), 91-99.

Pedroni, P. (2004). Panel cointegration: asymptotic and finite sample properties of pooled time series tests with an application to the PPP hypothesis. Economic Theory, 20, 597-625.

Phiri, A. (2016). Tourism and Economic Growth in South Africa: Evidence from linear and nonlinear cointegration frameworks. Managing Global Transitions, 14(1), 31-53.

Po, W. C. \& Huang, B. W. (2008). Tourism development and economic growth - a nonlinear approach. Physica A, 387(2008), 5535-5542.

Richardson, R. B. (2010). The contribution of tourism to economic growth and food security. Michigan, East Lansing: Michigan State University.

Rivera, M. A. (2017). The synergies between human development, economic growth, and tourism within a developing country: An empirical model for Ecuador. Journal of Destination Marketing \& Management, 6(3), 221-232.

SAinfo (South Africa info). (2015). Revisions to South Africa's amended visa regulations. http://www.southafrica.info/travel/south-africa-visa-amendments-261015.htm\#.WA039fVBusw Date of access: 16 Oct. 2016.

Samini, A. J., Sadeghi, S. \& Sadeghi, S. (2011). Tourism and economic growth in developing countries: P-VAR approach. Middle East Journal of Scientific Research, 10(1), 28-32.

Seghir, G. M., Mostéfa, B., Abbes, S. M. \& Zakarya, G. Y. (2015). Tourism spending- economic growth causality in 49 countries: A dynamic panel data approach. Procedia Economics and Finance, 23, 1613-1623.

Todaro, M. P. \& Smith, S. C. (2015). Economic development. 12 ${ }^{\text {th }}$ ed. Edinburgh Gate: Pearson Education Ltd. 
Trousdale, W. 2005. Promoting local economic development through strategic planning. The Local Economic Development Series, 1(1), 1-24.

UNWTO (The United Nations World Tourism Organization). (2016). Why tourism? http://www2.unwto.org/content/why-tourism Date of access: 2 Apr. 2016.

Van den Berg, H. (2012). Economic growth and development. $2^{\text {nd }}$ ed. Nebraska: World Scientific Publishing Co. Pty. Ltd.

WTTC (World Travel and Tourism Council). (2017a). Travel \& tourism economic impact 2017: South Africa. London: WTTC.

WTTC (World Travel and Tourism Council). (2017b). Understanding the critical issues for the future of travel and tourism, March 2017. London: WTTC.

Zuo, B. \& Huang, S. (2017). Revisiting the tourism-led economic growth hypothesis: The case of China. Journal of Travel Research, 1-13. 